This item was submitted to Loughborough's Research Repository by the author.

Items in Figshare are protected by copyright, with all rights reserved, unless otherwise indicated.

\title{
Individual variables with an impact on knowledge sharing: the critical role of employees' ignorance.
}

\section{PLEASE CITE THE PUBLISHED VERSION}

http://dx.doi.org/10.1108/JKM-04-2015-0153

\section{PUBLISHER}

(C) Emerald

\section{VERSION}

AM (Accepted Manuscript)

\section{PUBLISHER STATEMENT}

This work is made available according to the conditions of the Creative Commons Attribution-NonCommercialNoDerivatives 4.0 International (CC BY-NC-ND 4.0) licence. Full details of this licence are available at: https://creativecommons.org/licenses/by-nc-nd/4.0/

\section{LICENCE}

CC BY-NC-ND 4.0

\section{REPOSITORY RECORD}

Israilidis, John, Evangelia Siachou, Louise Cooke, and Russell Lock. 2019. "Individual Variables with an Impact on Knowledge Sharing: The Critical Role of Employees' Ignorance.”. figshare. https://hdl.handle.net/2134/18427. 


\title{
Individual variables with an impact on knowledge sharing: The critical role of employees' ignorance.
}

\begin{abstract}
:
Purpose: The purpose of this paper is to identify individual variables with an impact on knowledge sharing and explore the under-discussed construct of employees’ ignorance. This can enhance the knowledge sharing process and facilitate the development of greater intellectual capital.
\end{abstract}

Design/methodology/approach: Eighty-four dependent variables affecting knowledge sharing are analyzed and classified into eleven categories. In addition, the direct effect of employees’ ignorance on knowledge sharing is introduced and empirically investigated in a case study of a multinational organization operating within the Aerospace and Defense industry.

Findings: The findings suggest that employees' ignorance may negatively affect their intention to share knowledge, thus leading to poor decision-making and communication in organizations. Employees' ignorance could also limit the organizational ability to repel external threats, implement innovation and manage future risks.

Originality/value: A classification scheme based on different categories of employees' ignorance is developed, providing tailor-made recommendations for practitioners facing different types of ill-informed organizational scenarios. Further, the need to shift the emphasis away from the management of knowledge to the management of ignorance is also an important contribution of this paper.

Keywords: knowledge sharing; employees’ ignorance; moderating variables; aerospace and defense industry; multinational companies 


\section{Introduction}

In the era of the knowledge economy, organizations which are innovative performers need to manage effectively both the knowledge that is already stored in various organizational repositories and new knowledge that is externally derived (Jantunen, 2005). Such efforts can maximize organizational performance by improving productivity and overall efficiency of operations (Nonaka and Takeuchi, 1995). As organizational effectiveness is built upon employees’ knowledge, their involvement in knowledge sharing (e.g., face to face, virtual Communities of Practice, etc) has become one of the most prominent strategies for organizations looking to manage their knowledge assets effectively. Examples to support the above statement include but are not limited to Dow Chemical, Shell, Schlumberger, Cap Gemini Ernst \& Young and Best Buy (Vestal, 2002) and Caterpillar (Ardichvili et al., 2003). In recent times, though, the expansion of social media (such us Facebook, LinkedIn and Twitter) as well as other information technology tools (such as blogs, wikis and collaboration platforms) facilitates employees to exchange knowledge and ideas easily by joining groups, participating in virtual discussions, posting their own views and sharing information.

In addition to emerging collaborative technologies and organizational factors (such as culture, structure, management actions, etc) which are found to be influential for the sharing of knowledge within organizations, extant literature recognizes a set of variables that may also moderate (i.e., enable or prevent) knowledge sharing in organizations (Yoo and Torrey, 2002). Constructs, such as trust (e.g., Nahapiet and Ghoshal, 1998), anticipated reciprocal relationships (e.g., Bock et al., 2005; Chiu et al., 2006; Wasko and Faraj, 2005), identification (e.g., Kankanhalli et al., 2005), image (e.g., Wasko and Faraj, 2005), organizational rewards (e.g., Bock et al., 2005), knowledge self-efficacy (e.g., Bock et al., 2005; Jarvenpaa and Staples, 2000), and loss of knowledge power (e.g., Davenport and Prusak, 1998) have all been identified as factors with an impact on knowledge sharing. Beyond outlining these factors and 
despite previous research on organizational ignorance (Israilidis et al., 2012; Roberts, 2013; Zack, 1999), the literature lacks sufficient evidence to support whether employees' ignorance can function as a possible variable with an impact on knowledge sharing. It is instructive to define at this point the term employees' ignorance as the lack of knowledge, information or education, which implies lack of awareness about something and not the inability to understand; thus it is mainly caused by the circumstances of one's life and can be reduced through the acquisition of knowledge. Arguably, employees' unwillingness or tendency not to share the knowledge they possess while performing daily routine tasks and activities is likely to be related to the recipients' lack of appropriate knowledge, i.e., cognitive background. Furthermore, based on their ignorance, employees may underestimate the value of new knowledge to be acquired; thus they may justifiably feel that their participation in knowledge sharing activities is a futile process. Such difficulties, however, can be effectively managed when both knowledge keepers and seekers recognize the limits and extent of the knowledge they possess. In other words, employees should perceive the extent of their ignorance on a specific topic, subject or field, by actively exploring new knowledge to manage their unknowns.

Given the above discussion, this paper aims to identify individual variables with an impact on knowledge sharing and explore the under-discussed construct of employees' ignorance. Specifically, it examines individual variables that may impact on knowledge sharing and empirically investigates the direct effect of employees' ignorance on Knowledge Management (KM) using selected departments of one multinational organization within the Aerospace and Defense industry as embedded case studies. In addition, by analyzing different categories of employees' ignorance, the authors explore how different types of ill-informed organizational scenarios can impinge upon the knowledge sharing process. This enables those 
who are involved in knowledge sharing activities to enhance their understanding regarding the knowledge sharing process and facilitate the development of effective workplace learning.

The following section presents a review of the literature to identify individual variables with an impact on knowledge sharing. The third section outlines the methodology of the study and presents the empirical results. The fourth section discusses the findings while outlining implications for theory and practice and limitations. The concluding remarks are summarized in the last and fifth section.

\section{Research framework and hypotheses}

\subsection{Organizational knowledge sharing}

The sharing of knowledge within organizations has received considerable attention from both researchers and practitioners, leading to the identification of a number of variables related to either individual or organizational factors, such as employees' attitudes, organizational structures, and formal vs. informal relationships, which may affect it in either a positive or negative way (Ancona and Caldwell, 1992; Argote and Ingram, 2000; Dushnitsky and Lenox, 2005; Gupta and Govindarajan, 2000; Levin and Cross, 2004).

Apart from the above mentioned variables, extant literature also identifies significant factors with an impact on knowledge sharing such as the nature of knowledge to be shared i.e., tacit versus explicit (Polanyi, 1966) or codified versus personal (Hansen et al., 1999; Nonaka and Takeuchi, 1995; Zander and Kogut, 1995).

Reviewing the literature on the individual variables with an impact on knowledge sharing, 84 dependent variables which affect the sharing of knowledge in organizations were identified. These variables, in turn, have been classified into eleven categories: employees’ actions, attitudes, beliefs, emotions, expectations, motivators, needs, perceptions, traits, skills, behavior and authority and values, as shown in Table 1. 


\section{\{Place Table 1 about here\}}

Scholars in the field of KM approach knowledge sharing either as an individual behavior to share knowledge (i.e., send or receive), the individual's tendency or intention to share knowledge, the quality and quantity of the knowledge to be shared, or as employees' attitudes towards knowledge sharing (which has also been used either as a dependent or independent variable) and the subjective norms that dominate knowledge sharing. No matter how the sharing of knowledge has been approached, it is generally recognized that the sharing of organizational knowledge provides employees with beneficial outcomes. As such, Gupta et al. (2012b, p. 10) mention, among other individual benefits, the obligation of others to reciprocate, the level of self-esteem and the increased personal identification.

Current research pays particular attention to constructs which may, equally, determine employees’ behavior to knowledge sharing (e.g., Abzari and Abbassi, 2011; Gupta et al., 2012b; Kumar and Rose, 2012; Lin, 2007). Employees often share the knowledge they possess, predominantly, when they are intrinsically motivated (self-motivated) or when they anticipate specific personal benefits in return, such as enhanced reputation, perceived usefulness of the acquired knowledge, self-development, association, reciprocal relationships (e.g., Bock et al., 2005; Foss et al., 2009; He et al., 2009; Kankanhalli et al., 2005; Kwok and Gao, 2004; Lin, 2007). Likewise, employees share knowledge when they are driven by behavioral control (e.g., Ryua et al., 2003), enjoyment in helping others (e.g., Kim and Lee, 2011; Kumar and Rose, 2012) or in some cases when they choose to be socially engaged in knowledge exchange activities. As such, employees’ personal drivers seem to be collaborative factors for the sharing of organizational knowledge even if the structures or rules of their organizations do not support the appropriate knowledge transfer and sharing culture (Obembe, 2010). 
Considering the impact of expected rewards (a variable that has previously been broadly investigated) on individuals' knowledge sharing behaviors, the existing literature does not support a definitive relationship between these two variables; instead the findings are inconsistent and opposing. For instance, Burgess (2005) argues that expected rewards positively influence the knowledge sharing behavior of employees. On the other hand, Gupta et al. (2012b) claim that there is no consensus amongst scholars regarding the effect of rewards on knowledge sharing behavior in their study of 228 employees of two major Information Technology organizations in India. Although this may seem to be rather surprising since expected rewards would be perceived to be culturally very much a factor in knowledge sharing, their findings are also confirmed by the empirical work of Bock and Kim (2002), Bock et al. (2005) and Lin (2007) who all appear to suggest that expected rewards do not affect knowledge sharing behaviors.

On the subject of other variables, such as orientation to work (Jones et al, 2006), anticipated reciprocal relationships (Kim and Lee, 2011), organizational commitment (e.g., Gupta et al., $2012^{\mathrm{a}}$ ) as well as coercive and legitimate power, extant literature recognizes no significant effect on the sharing of organizational knowledge. Additionally, the usage of IT alone does not have any significant effect on the sharing of organizational knowledge. As such, it could be inferred that the individual variables with an impact on knowledge sharing are more closely related to perceived personal benefits and individual contributions rather than organizational settings, structures and command.

\subsection{Employees’ ignorance and knowledge sharing}

Although the value of knowledge sharing has been given significant attention, some of its variables are still unexplored. As organizational knowledge builds on employees’ 
knowledge, ill-informed or ignorant employees may negatively affect the organizational performance.

Ignorance has been considered by Pynchon (1984: 15-16) as a potential component for future success and achievement as it “[...] is not just a blank space on a person's mental map. It has contours and coherence, and for all I know rules of operation as well. So as a corollary to [the advice of] writing about what we know, maybe we should add getting familiar with our ignorance, and the possibilities therein for writing a good story". However, humans often find it intrinsically difficult to get a sense of what they don't know thus being unable to recognize their own incompetence (Kruger and Dunning, 1999). It can therefore be deduced that employees who make use of 'imperfect information' ${ }^{1}$ could increase the risks of making incorrect or inappropriate decisions and as such managing their ignorance could be perceived as a vital factor for organizational effectiveness. Since there is no common agreement on the use of the term employees' ignorance, the authors view this construct as organizational ignorance caused by employees’ unknowns regarding crucial organizational knowledge. Organizational ignorance, though, can be examined in relation to KM either as an antecedent to various knowledge management functions or a prerequisite for their successful implementation. Zack (1999), highlights that managing organizational ignorance can yield beneficial outcomes to corporations which successfully incorporate the fundamental KM processes in their strategy.

More recently, initial attempts have been made by Alvesson and Spicer (2012) to explore the value of managing organizational ignorance in relation to knowledge creation, sharing and transmission processes. In addition, a number of recent studies appear to suggest

\footnotetext{
${ }^{1}$ In this paper, the term 'imperfect information' is used to denote information that is neither precise nor certain. As Smets (1997) suggests, imperfection can be due to imprecision, inconsistency and uncertainty.
} 
that ignorance management could further improve knowledge sharing efforts within technology intensive organizations (Israilidis et al., 2012; Roberts, 2013).

Different assumptions regarding the nature (e.g., high and low volume) of knowledge and ignorance have been visually illustrated and identified by Israilidis et al. (2012) in a four quadrant diagram. Specifically, employees who demonstrate higher levels of ignorance may be characterized as ill-informed, whilst employees who demonstrate low levels of ignorance may be characterized as more competent and productive. Based on this viewpoint, individual and organizational trajectories to knowledge could be better explored and predicted in order to increase employees' capabilities in the workplace. For example, employees classified within the category of low level knowledge and high level ignorance could be characterized by poor knowledge sharing and collaboration skills due to the fact that they are more likely to give out incorrect information and hence place the company in a high-risk position knowledge-wise. Additionally, highly ignorant employees may be prevented from participating in knowledge sharing activities since they are lacking prior knowledge and experience which in itself reduces (or in some cases may eliminate) their ability to absorb new knowledge.

According to Cohen and Levinthal's (1990, p. 128) seminal work on absorptive capacity, "one's ability to recognize the value of new information, assimilate it and apply it to commercial ends is largely a function of the level of prior related knowledge”. As such, ignorance can also be seen as an obstacle to knowledge sharing since unaware employees may not be able to recognize the value of new knowledge acquired from external environments. In addition, the lack of knowledge regarding the existence or utilization of new technologies and tool-sets, such as current Knowledge Management Systems (KMS) available to employees, could also restrict knowledge flows in various organizational team discussions.

Based on the eleven categories presented in Table 1, employees' ignorance can be classified within the category of employees' traits, skills, abilities, behaviors and authority. As 
such, employees' ignorance can be viewed as an inability that prevents employees from effectively managing the knowledge possessed by organizations. On the other hand, employees who are well informed, thus less ignorant, can perform the appropriate skill-sets needed for the implementation of successful organizational knowledge sharing processes. As organizations build on employees' capabilities and competencies, it is proposed that employees’ ignorance could impede the sharing of knowledge and act as a barrier to their achievement of high level of knowledge and low level of ignorance.

\section{Methodology}

\subsection{Study context}

This research is focused in particular on multinational organizations where knowledge sharing is essential to both short-term opportunistic value capture and longer term business sustainability. Hence, this study took place within technology intensive environments and was conducted within a specific organizational context at DefenseCo ${ }^{2}$, which employs more than 60,000 employees across the globe and operates within the Aerospace, Defense and Information Security industry with worldwide interests. The company's employees are highly skilled within their respective field and the organization has attempted to create an environment specifically suited to knowledge exchange, transfer and sharing. As Jafari et al. (2007) note, one of the most important industries which should be managed competently from the knowledge point of view is the aerospace industry as the design and construction of aerospace systems has raised specific concerns, such as dealing with complexity, traceability, maturity of knowledge, interaction between experts, awareness of the status of information, and trust in knowledge. Therefore, in light of these observations, facilitating knowledge sharing is increasingly critical due to the ongoing pressure to boost efficiency.

\footnotetext{
${ }^{2}$ DefenseCo is a pseudonym that has been adopted to protect company anonymity.
} 


\subsection{Sample and data collection}

The data presented in this paper were collected through semi-structured interviews, as part of a larger research project, which aimed to explore the role of employees' ignorance in dysfunctional KM scenarios within an organizational context, part of which was to determine the relationship between employees’ ignorance and knowledge sharing.

The participants were self-selected from within a larger purposive sample gathered by questionnaire; however emphasis was placed upon senior executives and line managers at DefenseCo, in respect to their roles in managing $\mathrm{KM}$ projects and making decisions. Specifically, nine top-level employees from various backgrounds (including line leaders, project managers, review chairpersons, assessors and functional directors) and with different roles within the business were interviewed. Their daily tasks require direct, sustained involvement in knowledge sharing activities and other knowledge intensive processes, such as dealing with complex information and managing multiple projects simultaneously. As such, they all are actively engaged in several different knowledge sharing activities including sharing good practice, connecting people to people, supporting growth, stimulating innovation, auditing current systems and enhancing services. This enabled employees to perceive the study's concepts more accurately (Kumar et al. 1993) and allowed us to better understand whether employees' ignorance has an impact on the sharing of knowledge that takes place in their daily routine, tasks and activities.

The semi-structured interview instrument was designed to identify potential knowledge sharing barriers around knowledge and information management processes which are related to employees’ ignorance. Participants were asked, amongst others, to provide their perceptions regarding the knowledge sharing systems implemented by the organization, the 
value of knowledge sharing within the organization and their awareness regarding the organizational knowledge which is embedded in various repositories.

\subsection{Data analysis}

On average, the semi-structured interviews lasted approximately 45 to 50 minutes; however, participants were free to continue talking for as long as they wished, providing detailed comments about the topic in question. All interviews were recorded using a digital voice recorder and the analysis was conducted using the Atlas.ti computer assisted qualitative data analysis software due to the wide selection of built-in features and functionalities.

Coding was performed manually and patterns were identified and classified automatically via the use of the software program. The coding scheme was developed both inductively and deductively. If no theories were available to describe a particular phenomenon or verify an existing theory, categories were generated inductively from the data (Weber 1990). Example codes included: employees’ ignorance, networking, complex socio-technical systems, information anarchy, information overload, ill-informed messages, compliance, and good knowledge sharing practices, amongst others.

The data analysis uncovered patterns, themes, and categories important to both academia and business. However, because qualitative research is fundamentally interpretive, the researchers made every effort to achieve a balance between description and interpretation, supporting Patton's (2002: 503-504) view which argues that an interesting and readable research outcome "provides sufficient description to allow the reader to understand the basis for an interpretation, and sufficient interpretation to allow the reader to understand the description”. The following section presents the findings of the study which form the basis for future research implications discussed in a later section of this paper. 


\subsection{Findings}

The study suggests that managing employees' ignorance may yield effective knowledge sharing outcomes within organizations. The majority of the interviewees identified a direct negative relationship between high levels of employees’ ignorance and knowledge sharing, illustrating further, the benefits of interpersonal communications in addition to the use of applications and other computer-related software programs in managing knowledge effectively. Specifically, despite being time constrained, employees highlighted the role of face-to-face interaction (as opposed to technology) in reducing ignorance, emphasizing that informal ad hoc face-to-face communication can produce effective organizational outcomes. As such it was reported that:

"Because we are very busy at times, the opportunity for face-to-face networking within the business is not as active as it was. I personally think that it's better when people have the opportunity to work and to share ideas through working through a common thread".

"I think you have to go back to the human being to make it really work. The problem being there are savings, you drop all the people involved to try to make the system work and say you're actually going to be physically doing it rather than working on that digital cloud, you're actually going to be speaking with other people passing this information down, so human being; the human element”.

Based on the evidence from the current study, it is argued that knowledge sharing is more productive when physical interaction, not virtual, is present between knowledge seekers, without underestimating, though, the usefulness of social media including information technology tools, such as blogs, wikis and collaboration platforms, which can also facilitate knowledge sharing at the work place. As two employees simply stated: 
"I suppose I'm more of a people person [...] I'm not really someone that interfaces with the screen. I do and in fact I'm looking at one now but it is a tool for me to pass information, not necessarily to learn from”.

“Try not to get rid of the human element, keep the human element in and it will work”. In relation to organizational KM methods and practices that would enhance sharing opportunities, the interviewees noted the importance of involving seniors at a variety of levels to resolve deficiencies or compliance issues instead of merely relying on horizontal knowledge sharing.

Regarding the corporate knowledge itself, the study participants were found to be lacking in awareness of information in action (O'Dell and Hubert, 2011) and the capacity (potential or actual) to take effective action (Bennet and Bennet, 2008). This observation, though, is related to the ineffective KM systems implemented by the DefenseCo thus, stressing the importance of creating user-friendly and powerful information technology tools. Notably, it was indicated by a participant that:

"If I want to find out what's going on in other business areas for sharing best practice, the searching methodology doesn't work on our main corporate site. If you saw that number of results there was no way you would have the time to scroll through the results".

Furthermore, despite the fact that in recent years a lot of effort has been placed on enabling accurate and personalized results by improving ontologies, artificial intelligence and heuristics, it was found that the majority of tools lacked effective search mechanisms and the ability to filter down results based on the user's preferences within the case-study organization. As such employees could not make full and effective use of the existing technology to exchange knowledge. Besides, the available tools did not comprise 
comprehensive knowledge repositories; hence knowledge seekers appeared to be ignorant or ill-informed about the organizational knowledge stock.

"I struggle a bit with this, because Knowledge Sharing across the company, I don't think it's done very well. We all go on to the main website and we can read the handbooks and the guidebooks and the templates and everything, but there isn't any database of perhaps Learning from Experience, things that tell people what's gone right, what's gone wrong. There isn't anywhere that pulls our knowledge together”.

Informants were also found to be unaware of or ill-informed about the gate keepers of the corporate knowledge. In other words they face difficulties in identifying subject matter experts within the organization when they need to acquire or share specialized knowledge on time:

“At the moment it's just KM, I'm not quite sure that people understand what that is. Is it just retention of documents? How do we start to retain people's experiences as well which may have a bearing on the piece of work that we're about to undertake? Do we have a robust knowledge/register of qualified people? It's all about people - it is knowing who to go and talk to".

Based on the discussion above, this research shows that ineffective knowledge sharing is often caused by high levels of employees' ignorance, i.e., lack of crucial knowledge (or information at times) of various organizational settings, and can be classified as follows:

i) ignorance about the existence of subject matter experts with specialist knowledge within the organization;

(ii) ignorance about various KMS implemented by the organization as well as the way in which these systems can be used on a daily basis;

(iii) ignorance about the corporate knowledge itself (both codified and personal) which is embedded in various organizational repositories. 
The output of this classification is portrayed in Table 2 outlining the degree to which employees’ ignorance can act to inhibit organizational learning within an organization.

\{Place Table 2 about here

\section{Discussion}

In this study, it was found that employees' ignorance has a direct impact on knowledge sharing processes, thus restricting employees from participating in knowledge exchange and transfer activities on a daily basis.

As theory claims, knowledge sharing within organizations predicts a variety of desirable outcomes including increased productivity, decreased task completion time, increased organizational learning, innovativeness (e.g., Argote et al., 2003; Cummings, 2004; Hansen, 2002) and sustained competitive advantage (Gold et al., 2001). Organizations which operate in dynamic environments increasingly demand intensive participation in knowledge sharing activities (Davenport and Prusak, 1998; Drucker, 1985; Chow et al., 2008), either formally or informally, particularly when employees perform daily routine tasks and activities (Cummings, 2004). Based on prior literature on knowledge flows, it is instructive to note that knowledge transfer processes require particular attention to the value of the knowledge possessed by the source unit and the target unit's absorptive capacity for the incoming knowledge (Gupta and Govindarajan, 2000). From the empirical evidence, it appears that ignorant employees, i.e., those who lack critical organizational knowledge (tacit and/or explicit; codified and/or personal) may not be in a position to get involved in knowledge sharing activities. For instance, employees found to be ignorant of the knowledge possessed by the subject matter experts within the organization in which they are employed consume time and effort in seeking similar knowledge outside the organization's boundaries. Equally, employees' ignorance about KMS implemented by the organization restricts their ability to 
develop knowledge sharing skills which may lead them to the acquisition of obsolete or outof-date knowledge. In addition, ill-informed or ignorant employees may transmit incorrect information which might negatively affect the reputation of the organization, and are most likely to have difficulties in improving processes and completing projects on time. Hence, employees' ignorance could be viewed as an obstacle to organizational knowledge sharing as different types of ignorance can act to inhibit collaboration and knowledge enhancement within multinational organizations. In addition, the negative effect of employees' ignorance on knowledge sharing behaviors demonstrates the importance of acknowledging the existence of unknowns when sharing knowledge and recognizes the potential value of managing ignorance in the workplace.

As research findings suggest, interpersonal communications could facilitate knowledge sharing and decrease employees’ ignorance. Extant literature demonstrates several examples of actions to improve interpersonal communication, such as annual executives' conferences, formal and informal departmental meetings, ad-hoc situational committees, training sessions, speak-up groups and communities of practice which support the interaction among employees (Alavi and Leidner, 2001; Reagans and McEvily, 2003). In this study, it was evident that employees across different business units were using a plethora of systems to collaborate and exchange knowledge; however most of these tools were often found not to be interoperable and had limited searching capabilities from outside a given organizational unit. As such employees were not able to acquire knowledge from external sources making overall communications inflexible and ineffective. This observation is in line with the current literature and confirms the role of IT in knowledge sharing within organizations (Bock and Kim, 2002).

Additionally, it was discovered that, at a variety of levels, the administration appeared not to be involved in resolving deficiencies or compliance issues. It was therefore apparent 
that more frequent communication between managers and staff members is required, especially during meetings and debriefing sessions aimed at improving the knowledge sharing culture of the business.

Building on these observations and given the linkage between the variables of ignorance and knowledge sharing, it is inferred that high levels of employees' ignorance may result in significant performance consequences to organizations. For instance, in terms of managing external knowledge, employees who are unaware of the existence of new technologies, modifications of already existing products or services, and cost-efficient ways of managing operations within the business may not be able to implement innovation, i.e., make the appropriate decisions to adopt innovation (Klein and Sorra, 1996). Likewise, in terms of managing internal corporate knowledge, ignorant or ill-informed employees are likely to increase organizational costs by spending additional time and resources while searching for knowledge in various external knowledge repositories instead of using existing internal knowledge memories. Furthermore, ignorance prevents employees from recognizing the value and content of acquired knowledge and as such they are not able to make accurate decisions in terms of what needs to be assimilated from various external sources. As external knowledge is equally important for organizational development and success as the organizational knowledge stock, organizations need to take appropriate actions in order to ensure that external repositories do not overlap with existing internal knowledge stocks, limiting therefore the cost of knowledge duplication and transfer while enabling access to valuable new knowledge.

According to Nonaka and Takeuchi (1995), the creation of knowledge can only be seen as a process of knowledge sharing through articulating and internalizing knowledge processes. In addition, the sharing of ideas among employees is a key process underlying collective knowledge within an organization without which a company may not be able to 
leverage its most valuable asset, i.e., its human capital (Jarvenpaa and Staples, 2000). Nevertheless, employees’ ignorance can preclude knowledge sharing activities and could lead to poor decision-making and communication, which may inevitably affect the performance of operations while limiting the ability to repel external threats or manage future crisis situations. Hence, the necessity to review KM strategies on an ongoing basis and improve the efficiency and effectiveness of existing knowledge sharing processes has never been greater. Managers should find ways of managing ignorance, similar to how they would manage knowledge, to improve knowledge sharing and therefore devise ways to overcome problems that might arise within their industry.

\section{Concluding remarks}

This paper identifies a tentative link between ignorance and knowledge sharing and argues that managing employees’ ignorance could improve their knowledge sharing behavior. As very little of this discussion is captured by the current KM literature and no relationship has previously been identified between employees’ ignorance and knowledge sharing within the Aerospace and Defense industry, it is claimed that the effectiveness of knowledge sharing could be greatly improved, by understanding what needs to be known and also by acknowledging the existence of unknowns. Research findings also lead us to differentiate three types of employees' ignorance implying that dissimilar organizational ill-informed scenarios may differently affect knowledge sharing within organizations.

As no other factors were taken into account during the study analysis, a bidirectional relationship between ignorance and knowledge sharing cannot be confirmed. Additionally, since the study is based on a qualitative approach, it is proposed that the use of quantitative analysis could also be explored to support data generalizability as well as to confirm presence of a bidirectional relationship. Equally, additional studies need to be conducted to examine 
the linkage between ignorance and knowledge sharing by also considering the moderating or mediating effect of other variables such as environmental dynamism, absorptive capacity and various types of leadership. Finally, the study was conducted for an Aerospace and Defense organization; hence it may not reflect other corporate environments where agile and less hierarchical structures are established.

The study results have substantive implications for practitioners performing key roles in knowledge intensive organizations while striving to meet the challenges of current dynamic business environments. The study highlights the importance of smooth knowledge flows, and encourages the active consideration of ignorance in the management of organizational knowledge. From the perspective of academic research the study identifies the current state of both theory and practice in this area, but crucially also provides insights into the way in which ignorance impacts on the practical application of the state of the art within organizations. The importance of paying attention to managing unknowns as well as knowns is also an important implication for both practitioners and KM professionals alike.

By introducing the construct of employees' ignorance and discussing how it affects knowledge sharing, this work raises key questions which form the basis for future research and can be summarized as follows: How can employees’ ignorance be measured and reduced? Is there an acceptable threshold of employees' ignorance? What steps should managers take to become more aware of knowledge gaps and thus prevent dysfunctional KM situations that can affect the productivity of the business? Answers to these questions would open up new insights into managing knowledge and could undoubtedly help organizations in achieving sustained high performance.

It is important to acknowledge that it may not be surprising to find that employees’ ignorance impacts adversely on organizational performance and knowledge sharing. However, the novelty of this study is that it highlights a need to depart from the mere 
management of existing knowledge by also considering the management of ignorance, drawing attention to a very different paradigm into the maximization of organizational learning. This relates directly to existing discussions on unknown unknowns and facilitating knowledge flows, and as such, this approach brings new insights into the KM field.

\section{References}

Alavi, M. and Leidner, D. (2001), “Knowledge management and knowledge management Systems: Conceptual foundations and research issues”, MIS Quarterly, Vol. 25, No. 1, pp. 107-136.

Aliei, M., Ashrafi, B. and Aghayan, S. (2011), “Studying the relationship between organizational citizenship behavior and knowledge sharing”, Interdisciplinary Journal of Contemporary Research in Business, Vol. 3, No. 3, pp. 341-348.

Alvesson, M. and Spicer, A. (2012), “A stupidity based theory of organizations”, Journal of Management Studies, Vol. 49, No. 7, pp. 1194-1220.

Ancona, D. and Caldwell, D. (1992), "Bridging the boundary: External activity and performance in organizational teams”, Administrative Science Quarterly, Vol. 37, No. 4, pp. 634-665.

Appel-Meulenbroek, R. (2010), “Knowledge sharing through co-presence: added value of facilities”, Facilities, Vol. 28, No. 3/4, pp. 189-205.

Ardichvili, A., Page, V. and Wentling, T. (2003), “Motivation and barriers to participation in virtual knowledge-sharing communities of practice”, Journal of Knowledge Management, Vol. 7, No. 1, pp. 64-77.

Argote, L. and Ingram, P. (2000), “Knowledge transfer: A basis for competitive advantage in firms”, Organizational Behavior and Human Decision Processes, Vol. 82, No. 1, pp. 150-169. 
Bennet, D. and Bennet, A. (2008), “The depth of knowledge: surface, shallow or deep?” VINE, Vol. 38, No. 4, pp. 405-420.

Bock, G-W. and Kim, Y-G. (2002), “Breaking the myths of rewards: An exploratory study of attitudes about knowledge sharing”, Information Resources Management Journal, Vol. 15, No. 2, pp. 14-21.

Bock, G-W., Zmud, R.W., Kim, Y-G. and Lee, J-N. (2005), “Behavioral intention formation in knowledge sharing: Examining the roles of extrinsic motivators, socialpsychological forces, and organizational climate”, MIS Quarterly, Vol. 29, No. 1, pp. 87-111.

Burgess, D. (2005), “What motivates employees to transfer knowledge outside their work unit?”, Journal of Business Communication, Vol. 42, No. 4, pp. 324-348.

Chiu, C.-M., Hsu, M.-H. and Wang, E. (2006), “Understanding knowledge sharing in virtual communities: An integration of social capital and social cognitive theories”, Decision Support Systems, Vol. 42, No. 3, pp. 1872-1888.

Chow, W.S. and Chan, L. S. (2008), "Social network, social trust and shared goals in organizational knowledge sharing”, Information \& Management, Vol. 45, No. 7, pp. 458-465.

Cohen, W.M. and Levinthal, D. A. (1990), “Absorptive capacity: A new perspective on learning and innovation”, Administrative Science Quarterly, Vol. 35, No. 1, pp. 128-152.

Constant, D., Kiesler, S. and Sproull, L. (1994), "What's mine is ours, or is it? A study of attitude about information sharing”, Information Systems Research, Vol. 5, No. 4, pp. 400422.

Davenport, T. and Prusak, L. (1998). Working Knowledge: How Organizations Manage What They Know, Harvard Business School Press, Cambridge, MA.

Dushnitsky G. and Lenox, M. (2005), "When do incumbents learn from entrepreneurial ventures? Corporate venture capital and investing firm innovation rates”, Research Policy, Vol. 34, No. 5, pp. 615-639. 
Foss, N., Minbaeva, D., Pedesren, T. and Reinholt, M. (2009), “Encouraging knowledge sharing among employees: How job design matters”, Human Resource Management, Vol. 48, No. 6, pp. 871-893.

Gupta, A.K. and Govindarajan, V. (2000), “Knowledge flows within multinational corporations”, Strategic Management Journal, Vol. 21, No. 4, pp. 473-496.

Gupta, B., Agarwal, A., Samaria, P., Sarda, P. and Bucha, R. (2012a), “Organizational commitment \& psychological contract in knowledge sharing behaviour”, The Indian Journal of Industrial Relations, Vol. 47, No. 4, pp. 737-749.

Gupta, B., Joshi, S. and Agarwal, M. (2012b), “The effect of expected benefit and perceived cost on employees’ knowledge sharing behavior: A study of IT employees in India”, Organizations and Markets in Emerging Economies, Vol. 3, No. 1, pp. 8-19.

Hansen, M., Nohria N. and Tierney, T. (1999), “What’s your strategy for managing knowledge”? Harvard Business Review, Vol. 77, No. 2, pp. 106-116.

He, W., Qiao Q. and Wei, K.-K. (2009), “Social relationship and its role in knowledge management systems usage”, Information \& Management, Vol. 46, No. 3, pp. 175-180.

Hsu, C.-L. and Lin, C.-C. (2008), “Acceptance of blog usage: The roles of technology acceptance, social influence and knowledge sharing motivation”, Information \& Management, Vol. 45, No. 1, pp. 65-74.

Iqbal, S., Toulson, P. and Tweed, D. (2010), “The impact of HRM practices on organisational capability mediated by knowledge sharing: A conceptual model”, in Proceedings of the 7th International Conference on Intellectual Capital, Knowledge Management and Organisational Learning Conference (ICICKM) in Hong Kong, China, 2010, Academic Publishing International, Reading, pp. 195-204.

Israilidis, J., Lock, R. and Cooke, L. (2012), “Ignorance management: An alternative perspective on knowledge management in multinational organisations”, in Proceedings of the 
13th European Conference on Knowledge Management Conference (ECKM) in Cartagena, Spain, Academic Publishing International., Readung, pp. 493-501.

Jafari, M., Akhavan, P., Nour, J.R. and Fesharaki, M. (2007), “Knowledge management in Iran aerospace industries”, Aircraft Engineering and Aerospace Technology: An International Journal, Vol. 79, No. 4, pp. 375-389.

Jantunen, A. (2005), “Knowledge-processing capabilities and innovative performance: an empirical study”, European Journal of Innovation Management, Vol. 8, No. 3, pp. 336349.

Jarvenpaa, S.L. and Staples, D.S. (2000), “The use of collaborative electronic media for information sharing: An exploratory study of determinants”, Journal of Strategic Information Systems, Vol. 9, No. 2, pp. 129-154.

Jones, M.C., Cline, M. and Ryan, S. (2006), “Exploring knowledge sharing in ERP implementation: an organizational culture framework”, Decision Support Systems, Vol. 41, No. 2, pp. 411-434.

Joy, A. and Haynes, B. (2011), “Office design for the multi-generational knowledge workforce”, Journal of Corporate Real Estate, Vol. 13, No. 4, pp. 216-232.

Kankanhalli, A., Bernard C. and Wei, K.-K. (2005), “Contributing knowledge to electronic knowledge repositories: An empirical investigation.” MIS Quarterly, Vol. 29, No. 1, pp. 113-143.

Kim, T. and Lee, G. (2011), “A modified and extended Triandis model for the enablers-process-outcomes relationship in hotel employees' knowledge sharing”, The Service Industries Journal, Vol. 32, No. 13, pp. 2059-2090.

Klein, K.J. and Sorra, J.S. (1996), “The challenge of innovation implementation”, Academy of Management Review, Vol. 21, No. 4, pp. 1055-1083. 
Kruger, J. and Dunning, D. (1999), “Unskilled and unaware of It: How difficulties in recognizing one's own incompetence lead to inflated self-assessments”, Journal of Personality and Social Psychology, Vol. 77, No. 6, pp. 1121-1134.

Kumar, N. and Rose, R. (2012), “The impact of knowledge sharing and Islamic work ethic on innovation capability”, Cross Cultural Management: An International Journal, Vol. 19, No. 2, pp. 142-165.

Kwok, J.S. and Gao, S. (2004), “Knowledge sharing community in P2P network: a study of motivational perspective”, Journal of Knowledge Management, Vol. 8, No. 1, pp. 94102.

Levin, D. and Cross, R. (2004), “The strength of weak ties you can trust: The mediating role of trust in effective knowledge transfer”, Management Science, Vol. 50, No. 11, pp. 1477-1490.

Liao, L. (2006), “A learning organization perspective on knowledge-sharing behavior and firm Innovation”, Human Systems Management, Vol. 25, No. 4, pp. 227-236.

Liao, L. (2008), “Knowledge-sharing in R\&D departments: a social power and social exchange theory perspective”, The International Journal of Human Resource Management, Vol. 19, No. 10, pp. 1881-1895.

Lin, H. and Lee, G. (2004), “Perceptions of senior managers toward knowledgesharing behaviour”, Management Decision, Vol. 42, No. 1, pp. 108-125.

Lin, H. (2007), “Effects of extrinsic and intrinsic motivation on employee knowledge”, Journal of Information Science, Vol. 33, No. 2, pp. 135-149.

Lin, C. and Joe, S. (2012), "To share or not to share: Assessing knowledge sharing, interemployee helping, and their antecedents among online knowledge workers”, Journal of Business Ethics, Vol. 108, No. 4, pp. 439-449. 
Marks, P., Polak, P., Mccoy, S. and Galletta, D. (2008), “Sharing Knowledge”, Communications of the ACM, Vol. 51, No. 2, pp. 60-65.

Michailova, S. and Minbaeva, D. (2012), “Organizational values and knowledge sharing in multinational corporations: The Danisco case”, International Business Review, Vol. 21, No. 1, pp. 59-70.

Nahapiet, J. and Ghoshal, S. (1998), “Social capital, intellectual capital, and organizational advantage”, Academy of Management Review, Vol. 23, No. 2, pp. 242-266.

Nonaka, I. and Takeuchi, H. (1995), The knowledge-creating company: How Japanese companies create the dynamics of innovation, Oxford University Press, New York, NY.

Nonaka, I. and Toyama, R. (2003), “The knowledge-creating theory revisited: Knowledge creation as a synthesizing process”, Knowledge Management Research \& Practice, Vol. 1, No. 1, pp. 2-10.

Obembe, D. (2010), “Understanding individual action: When employees contravene management directives to foster knowledge sharing”, Management Research Review, Vol. 33, No. 6, pp. 656-666.

O’Dell, C. and Hubert, C. (2011), The New Edge in Knowledge: How Knowledge Management is Changing The Way We Do Business, John Wiley \& Sons, Hoboken, NJ.

Panteli, N. and Sockalingam, S. (2005), “Trust and conflict within virtual interorganizational alliances: A framework for facilitating knowledge sharing”, Decision Support Systems, Vol. 39, No. 4, pp. 599-617.

Patton, M.Q. (2002), Qualitative Research and Evaluation Methods, Sage, Thousand Oaks, CA.

Polanyi, M. (1966), The Tacit Dimension, Routledge \& Kegan Paul, London, UK. Pynchon, T. (1984), Slow Learner: Early Stories, Little Brown, Boston, MA. 
Roberts, J. (2013), “Organizational ignorance: Towards a managerial perspective on the unknown”, Management Learning, Vol. 44, No. 3, pp. 215-236.

Ryua, S., Hob, S.H. and Hanb, I. (2003), “Knowledge sharing behavior of physicians in hospitals”, Expert Systems With Applications, Vol. 25, No. 1, pp. 113-122.

Shin, S.K., Ishman, M. and Sanders, G.L. (2007), “An empirical investigation of sociocultural factors of information sharing in China”, Information \& Management, Vol. 44, No.2, pp. 165174.

Smets, P. (1997), “Imperfect information: Imprecision and uncertainty”, in Motro, A. and Smets, P. (Eds.), Uncertainty Management in Information Systems, Springer, New York, NY, pp. 225-254.

Teh, P. and Sun, H. (2012), “Knowledge sharing, job attitudes and organisational citizenship behaviour”, Industrial Management \& Data Systems, Vol. 112, No. 1, pp. 64-82.

Vestal, W. (2002), Measuring Knowledge Management, APQC, available at http://www.providersedge.com/docs/km_articles/Measuring_KM.pdf (accessed: 23.05.2011).

Wang, C. (2004), “The influence of ethical and self-interest concerns on knowledge sharing intentions among managers: An empirical study”, International Journal of Management, Vol. 21, No. 3, pp. 370-381.

Wang, J., Gwebu, K., Shanker, M. and Troutt, M.D. (2009), “An application of agentbased simulation to knowledge sharing”, Decision Support Systems, Vol. 46, No. 2, pp. 532541.

Wasko, M.M. and Faraj, S. (2005), “Why should I share? Examining social capital and knowledge contribution in electronic networks of practice”, MIS Quarterly, Vol. 29, No. 1, pp. 35-57.

Weber, R.P. (1990), Basic Content Analysis, Sage Publications, Newbury Park, CA. 
Yanga, S. and Farn, C. (2009), “Social capital, behavioural control, and tacit knowledge sharing-A multi-informant design”, International Journal of Information Management, Vol. 29, No. 3, pp. 210-218.

Yoo, Y. and Torrey, B. (2002), “National culture and knowledge management in a global learning organization”, in Choo, C.W. and Bontis, N. (Eds), The Strategic Management of Intellectual Capital and Organizational Knowledge, Oxford University Press, Oxford, pp, 421-434.

Zack, M. (1999), “Managing organizational ignorance”, Knowledge Directions, Vol. 1, pp. 36-49. 
Table 1: Key studies that demonstrate the impact of individual variables on knowledge sharing

\begin{tabular}{|c|c|c|c|}
\hline & $\begin{array}{l}\text { Categories of individual } \\
\text { variables }\end{array}$ & $\begin{array}{l}\text { Dependent individual variables (as extracted from } \\
\text { the literature) }\end{array}$ & Author(s) in alphabetic order \& Publication Year \\
\hline (1) & Employees' attitudes & $\begin{array}{l}\text { Attitudes towards KS, attitudes toward organization, } \\
\text { collectivism, espousement, intention to KS, job } \\
\text { satisfaction, loyalty, organizational commitment, } \\
\text { orientation to collaboration, orientation to change, } \\
\text { orientation to work. }\end{array}$ & $\begin{array}{l}\text { Abzari and Abbasi (2011); Aliei et al (2011); Bock and } \\
\text { Kim (2002); Bock et al (2005); Chow and Chan (2008), } \\
\text { Gupta et al (2012); Hsu and Lin (2008); Jones et al } \\
\text { (2006); Lin (2007); Michailova and Minbaeva (2912); } \\
\text { Ryua et al (2003); Shin et al (2007); Teh and Sun (2012); } \\
\text { Wasko and Faraj (2000); Zhang and Ng (2012). }\end{array}$ \\
\hline (2) & Employees’ beliefs & $\begin{array}{l}\text { Psychological contract fulfillment, (knowledge) self- } \\
\text { efficacy, basis of truth and rationality, self } \\
\text { consistency. }\end{array}$ & $\begin{array}{l}\text { Constant et al (1994); Gupta et al (2012 }) \text {; Jones et al } \\
\text { (2006); Kumar and Rose (2012); Lin (2007); Kim and Lee } \\
\text { (2011). }\end{array}$ \\
\hline (3) & Employees’ needs & $\begin{array}{l}\text { Affiliation, identification, reputation, linking } \\
\text { (networking), personal needs. }\end{array}$ & Chiu et al (2006); Kwok and Gao (2004). \\
\hline (4) & Employees’ perceptions & $\begin{array}{l}\text { Perceived behavioral control, perceived ease of use of } \\
\text { KMS, perceived usefulness of KM; perceived } \\
\text { enjoyment, perceived cost, personal perceptions, } \\
\text { considerations of past experience, self-image, } \\
\text { prospective engagements in practice, enjoyment in } \\
\text { helping others, personal benefit from contributions, } \\
\text { self-worth through KS behavior, self-development; } \\
\text { enhanced reputation, psychological contract breach. }\end{array}$ & $\begin{array}{l}\text { Abzari and Abbasi (2011); Aliei et al (2011); Bock et al } \\
\text { (2005); Gupta et al (2012 }) \text {; Gupta et al (2012 }) \text {; He et al } \\
\text { (2009); Hsu and Lin (2008); Kim and Lee (2011); Kumar } \\
\text { and Rose (2012); Ryua et al (2003); Obembe (2012); } \\
\text { Wang et al (2009); Wasko and Faraj (2000); Zhang and } \\
\text { Ng (2012). }\end{array}$ \\
\hline (5) & $\begin{array}{l}\text { Employees’ traits, skills, } \\
\text { abilities, behaviors and } \\
\text { authority }\end{array}$ & $\begin{array}{l}\text { Work experience, task identified employees, } \\
\text { orientation to change, orientation to work, orientation } \\
\text { to collaboration, orientation and focus, intention to } \\
\text { KS, internal control, individual initiative, flow } \\
\text { experience, coordination and responsibility, level of } \\
\text { IT usage, over knowledge, civic virtue, inter- } \\
\text { employee helping, helping behavior, Confucian } \\
\text { dynamism; extensive social networking; job } \\
\text { autonomous employees, coercive power, legitimate }\end{array}$ & $\begin{array}{l}\text { Aliei et al (2011); Chow and Chan, (2008); Bock and Kim } \\
\text { (2002); Constant et al (1994); Foss et al (2009); Constant } \\
\text { et al (1994); Jones et al (2006); Liao (2008), Lin and Joe } \\
\text { (2012); Shin et al (2007); Wasko and Faraj (2000); Yanga } \\
\text { and Farn (2009); Zhang and Ng (2012). }\end{array}$ \\
\hline
\end{tabular}




\begin{tabular}{|c|c|c|c|}
\hline & & power, reference power, expert power. & \\
\hline (7) & Employees' expectations & $\begin{array}{l}\text { Anticipated extrinsic rewards, anticipated reciprocal } \\
\text { relationships, anticipated usefulness, expected } \\
\text { associations, expected contribution, expected } \\
\text { reciprocal benefit, personal outcome expectations, } \\
\text { community related expectations. }\end{array}$ & $\begin{array}{l}\text { Bock and Kim (2002); Bock et al (205); Chiu et al } \\
\text { (2006); Gupta et al (2012b); Hsu and Lin (2008); Lin } \\
\text { (2007); Kim and Lee (2011). }\end{array}$ \\
\hline (8) & Employees’ values & $\begin{array}{l}\text { Self-expression, trust/trusting relationships, altruism, } \\
\text { self-interest, concerns, self-interest concerns, } \\
\text { sportsmanship, ethical concerns. }\end{array}$ & $\begin{array}{l}\text { Aliei et al (2011); Chiu et al.(2006); Constant et al } \\
\text { (1994); He et al (2009); Hsu and Lin (2008); Jones et al } \\
\text { (2006); Kumar and Rose (2012); Kwok and Gao (2004); } \\
\text { Michailova and Minbaeva (2012); Wang (2004). }\end{array}$ \\
\hline (9) & Employees' emotions & Job involvement. & Teh and Sun (2012). \\
\hline (10) & Employees' actions & Organizational Citizenship Behavior. & Teh and Sun (2012). \\
\hline (11) & Employees’ motivators & $\begin{array}{l}\text { Self-interest, self-development, rewards, affiliation, } \\
\text { employees intrinsically motivated, employees external } \\
\text { motivations, employees motivated by introjection. }\end{array}$ & $\begin{array}{l}\text { Bock et al (2005); Foss et al (2009); Joy and Haynes } \\
\text { (2011); Liao (2006); Lin (2007); Lin and Joe (2012); } \\
\text { Wang (2004); Yanga and Farn (2009). }\end{array}$ \\
\hline
\end{tabular}


Table 2: Ignorance classification - Detailed Findings

\begin{tabular}{|c|c|c|}
\hline No & Representative quotes from employees & Classification* \\
\hline (1) & $\begin{array}{l}\text { "In an organization like ours, we tend to think that it's } \\
\text { got lots of information and data stored on computers } \\
\text { and we need to access that. I think, actually, what you } \\
\text { need to do is maximize the use of knowledge, and the } \\
\text { knowledge bit is actually stored in the people. So you } \\
\text { need to know who to go to and have access to them". }\end{array}$ & (1) \\
\hline (2) & $\begin{array}{l}\text { "At the moment it's just KM, I'm not quite sure that } \\
\text { people understand what that is. Is it just retention of } \\
\text { documents? How do we start to retain people's } \\
\text { experiences as well which may have a bearing on the } \\
\text { piece of work that we're about to undertake? Do we } \\
\text { have a robust knowledge/register of qualified people? } \\
\text { It's all about people - it's knowing who to go and talk } \\
\text { to". }\end{array}$ & (1) \\
\hline (3) & $\begin{array}{l}\text { "It needs to be more integrated with daily management. } \\
\text { So maybe we could set some kind of objective around } \\
\text { making sure that knowledge is not only captions stored } \\
\text { but it's shared between the team". }\end{array}$ & $(2)$ \\
\hline (4) & $\begin{array}{l}\text { "I'm not aware of any knowledge sharing tools [...] } \\
\text { The only tools that I really use are my own eyeballs } \\
\text { looking down the list of assets". }\end{array}$ & $(2)$ \\
\hline (5) & $\begin{array}{l}\text { "I think lot of us struggled with that question around } \\
\text { Knowledge Sharing and what those tools were, because } \\
\text { we're not aware of any specific Knowledge Sharing } \\
\text { tools". }\end{array}$ & $(2)$ \\
\hline (6) & $\begin{array}{l}\text { "You would do a search, for example Knowledge Capture, } \\
\text { and within our database it came up with } 7640 \text { results. And } \\
\text { then I thought well, what's the point in Knowledge } \\
\text { Capture process". }\end{array}$ & $(2)$ \\
\hline (7) & $\begin{array}{l}\text { "If I want to find out what's going on in other business } \\
\text { areas for sharing best practice, the searching methodology } \\
\text { doesn't work on our main corporate site. If you saw that } \\
\text { number of results there was no way you would have the } \\
\text { time to scroll through the results". }\end{array}$ & $(2)$ \\
\hline (8) & $\begin{array}{l}\text { "I struggle a bit with this, because Knowledge Sharing } \\
\text { across the company, I don't think it's done very well. } \\
\text { We all go on to the main website and we can read the } \\
\text { handbooks and the guidebooks and the templates and }\end{array}$ & (3) \\
\hline
\end{tabular}




\begin{tabular}{|l|l|l|}
\hline & $\begin{array}{l}\text { everything, but there isn't any database of perhaps } \\
\text { Learning from Experience, things that tell people } \\
\text { what's gone right, what's gone wrong. There isn't } \\
\text { anywhere that pulls our knowledge together”. }\end{array}$ & $\begin{array}{l}\text { "More up and down feedback just in general } \\
\text { communications would help”. }\end{array}$ \\
\hline (9) & (3) \\
\hline
\end{tabular}

* (1): ignorance of subject matter experts

(2): ignorance of KMS

(3): ignorance of the corporate knowledge itself 